\title{
Prospective study on the effects of a polypropylene prosthesis on testicular volume and arterial flow in patients undergoing surgical correction for inguinal hernia ${ }^{1}$
}

\author{
Estudo prospectivo dos efeitos da prótese de polipropileno sobre o volume e o fluxo \\ arterial testicular em pacientes submetidos à correção cirúrgica de hérnia inguinal
}

\author{
Edgar Valente de Lima Neto², Alberto Goldenberg ${ }^{3}$, Mário Jorge Jucá ${ }^{4}$ \\ 1. Reserach performed at Postgraduate Program on Surgical Gastroenterology, Federal University of São Paulo (UNIFESP), São Paulo, Brazil. \\ 2. Master, Fellow PhD degree, Associate Professor, University of Health Sciences of Alagoas (UNCISAL) and the Federal University of Alagoas \\ (UFAL), Alagoas, Brazil. \\ 3. PhD, Associate Professor, UNIFESP, São Paulo, Brazil. \\ 4. PhD, Associate Professor, UFAL, Alagoas, Brazil.
}

\begin{abstract}
Purpose: To evaluate testicular volume and arterial flow in patients undergoing surgical correction for inguinal hernia, with polypropylene prosthesis. Methods: This was an observational prospective clinical study on 39 male patients with unilateral inguinal hernia of types III A and III B according to the Nyhus classification who underwent surgical correction with implantation of a polypropylene prosthesis by means of the Lichtenstein technique. The patients were evaluated using Doppler ultrasound before the operation and selectively at the third and sixth months after the operation. The variables studied were testicular volume, systolic and diastolic velocity, resistance index and pulsatility index. Results: No statistically significant alterations in the variables studied were observed over the course of time: testicular volume ( $p=0.197)$; systolic velocity $(p=0.257)$; diastolic velocity $(p=0.554)$; resistance index $(p=0.998)$; and pulsatility index $(p=0.582)$. Conclusion: No alteration in testicular volume and arterial flow over a six-month period was observed among patients who underwent surgical correction for inguinal hernia using a polypropylene prothesis.
\end{abstract}

Key words: Testis. Surgical Mesh. Hernia, Inguinal.

\section{RESUMO}

Objetivo: Avaliar o volume testicular e o fluxo na artéria testicular em pacientes operados de inguinal com prótese de polipropileno. Métodos: Estudo clínico prospectivo observacional em 39 pacientes do sexo masculino portadores de hérnia inguinal tipo III A e III B na classificação de Nyhus os quais foram submetidos a hernioplastia inguinal com implantação de prótese de polipropileno com a técnica de Lichtenstein. Os pacientes foram avaliados com ultra-sonografia Doppler no pré-operatório; no $3^{\circ}$ mês e no $6^{\circ}$ mês de pós-operatório. As variáveis estudadas foram: volume testicular; velocidade sistólica e diastólica, o índice de resistividade e o índice de pulsatilidade. Resultados: Não se observou alterações estatisticamente significantes nas variáveis ao longo do tempo: volume testicular ( $\mathrm{p}=0,197)$; velocidade sistólica ( $\mathrm{p}=0,257)$; velocidade diastólica $(\mathrm{p}=0,554)$; índice de resistividade $(\mathrm{p}=0,998)$; índice de pulsatilidade $(\mathrm{p}=0,582)$. Conclusão: Não se observou alteração no volume testicular e no fluxo sanguíneo da artéria testicular após seis meses nos pacientes submetidos à correção cirúrgica de hérnia inguinal com prótese de polipropileno..

Descritores: Testículo. Telas Cirúrgicas. Hérnia Inguinal. 


\section{Introduction}

Every year, more than one million polypropylene prostheses are implanted for treating hernias around the world $^{1,2}$. Over the evolution of treatments for inguinal hernia, it has been discovered that the use of prostheses is fundamental for obtaining low recurrence rates and high satisfaction rates ${ }^{3,4,5}$. The euphoria triggered by the results from multicenter studies regarding the use of prostheses made many authors conclude that the possibility of recurrence and the postoperative complications from inguinal hernias were problems that had been solved ${ }^{6,7}$. The following complications caused by the use of prostheses have been described: fistulas, infection, extrusion, chronic pain, migration of the prosthesis to the bladder and to the intestines, and peritoneal adherence ${ }^{5,9}$. Nyhus ${ }^{10}$ overcome various fears and encouraged the scientific community to use prostheses. Inguinal hernia may impair fertility by causing changes in testicular flow, as observed by Beddy et al. ${ }^{11}$. Yavetz et al. ${ }^{12}$ studied 8,500 infertile men with and without testicular atrophy and found that 565 of the men without testicular atrophy (6.65\%) had undergone inguinal hernioplasty. Uzzo et al. ${ }^{13}$ in an experimental canine model, observed that the polypropylene prosthesis promoted a fibroblastic response that could lead to the formation of fibrotic adherences between the mesh and the spermatic funiculus. They also observed changes in temperature, testicular volume, testosterone levels, blood perfusion and reduction in the diameter of the vas deferens, which were attributed to the foreign-body reaction caused by the prostheses. The testicular histology and spermatic motility and morphology may also be impaired, according to these authors ${ }^{13}$. Klinge et al. ${ }^{14}$ reoperated 17 patients in whom prostheses had been implanted and they observed the following histological alterations: foreign-body reaction; granuloma with epithelial cells and giant cells, fibrinoid necrosis in some cases and extensive collagen deposits. According to these authors, these tissue reactions caused a contraction of the prosthesis, with reduction to $60 \%$ of its original size ${ }^{14}$. Goldenberg et al. ${ }^{15}$, in a study carried out on ten dogs, observed the effects of the polypropylene prosthesis on the testicle, epididymis and vas deferens. Polypropylene prostheses were implanted in the animals' inguinal region and, thirty days later, they were subjected to another operation to remove their testicles and spermatic funiculus. These authors concluded that there had been histological changes, with $20 \%$ reduction in the animals' spermatogenesis and an inflammatory process involving the vas deferens in $60 \%$ of the animals. Aydede et al. ${ }^{16}$ studied perfusion and testicular function in a randomized clinical trial involving two groups of 30 patients who underwent surgical correction for inguinal hernia, by means of a prosthesis. Group I was operated using the Lichtenstein technique and group II was operated using the totally extraperitoneal technique (TEP). Alterations to testicular blood flow were observed on the third postoperative day in both groups. Akbulut et al. ${ }^{17}$ also evaluated the effects of prostheses on testicular function and volume using the Lichtenstein and laparoscopic TEP techniques. Twenty-six patients allocated into two groups of 13 were studied. They concluded that there were changes in testosterone levels and in testicular volume in the group operated using TEP, in comparison with the group operated using the Lichtenstein technique. Goldenberg and De Paula ${ }^{18}$ carried out an experimental study to observe the effects of a polypropylene mesh implanted by means of inguinotomy, on the spermatic funiculus. They used 18 dogs distributed into three groups: group $A(n=7)$, left side with mesh and right side without mesh; group $B(n=7)$, left side without mesh and right side with mesh; and group $C(n=4)$, without surgical manipulation, i.e. control group. After 60 days, the animals underwent removal of the spermatic funiculus, epididymis and testicles. On the side with the mesh, it was observed that all the animals presented adherences between the spermatic funiculus and the posterior wall, and also an inflammatory reaction of foreign-body type that involved the vas deferens. On the side without the mesh, $71 \%$ of the animals presented chronic inflammatory reaction. Shin et al. ${ }^{19}$ studied 14 patients with azoospermia secondary to obstruction of the vas deferens following surgical correction of hernias using prostheses. An exploratory operation revealed dense fibroblastic reaction involving the mesh and obstructing the vas deferens. They concluded that there was a relationship between the prostheses and the cases of infertility due to obstruction of the vas deferens ${ }^{19}$. Fitzgibbons ${ }^{20}$ commented that infertility could be caused by an iatrogenic effect on the vas deferens or by testicular damage. This author's conclusion was that infertility is a complication from surgical corrections for hernias carried out with or without prostheses ${ }^{20}$. The use of prostheses for surgical corrections for inguinal hernias reaches beyond a worldwide consensus: it is also an ethical management method, since it provides high satisfaction rates with low recurrence rates ${ }^{8}$. Nonetheless, it is necessary to continuously study the effects of prostheses on flow and testicular volume ${ }^{19}$.

\section{Methods}

This study was granted approval by the Research Ethics Committee of the Federal University of São Paulo (UNIFESP). This was an observational prospective clinical study on 39 male patients with unilateral inguinal hernia. Their mean age was 49.6 years. The hernia was on the right side in 27 cases and on the left side in 12 cases, and 24 were hernias of type III-A and 15 were III-B in the Nyhus classification. Patients were excluded if their hernias were bilateral, relapsed, femoral, 
incarcerated or strangulated. They were also excluded if they were less than 21 years old; had undergone previous operations on the scrotum, testicles or prostate; had undergone pelvic radiotherapy; presented diabetes; or presented chronic arterial or venous diseases. The patients were operated by the same surgeon, who was experienced in surgical correction for hernias. The Lichtenstein technique was used for the surgical correction of the hernias. The polypropylene prostheses were made of prolene mesh of Ethicon ${ }^{\circledR}$ brand. The anesthesia utilized was spinal block. The patients were evaluated by means of Doppler ultrasonography, using the Philips ${ }^{\circledR}$ EnVisor $\mathrm{C}$ apparatus, with 7.5-MHz linear

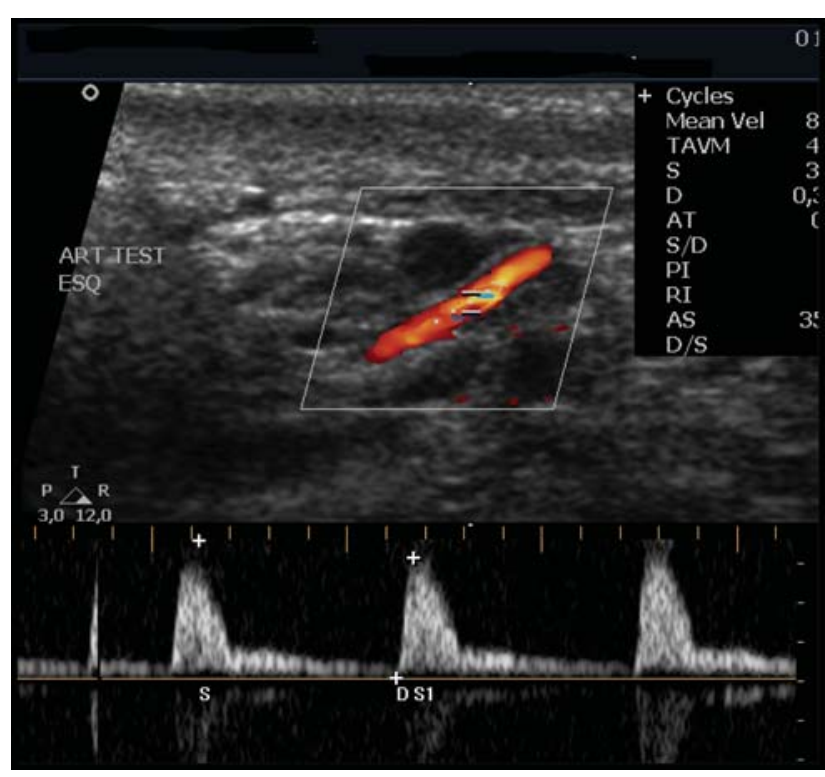

FIGURE 1 - Doppler ultrasonography showing the testicular artery in red transducers. The testicular artery was identified in its distal portion, at a distance of $1 \mathrm{~cm}$ from the upper pole of the testicle, by using a transducer with angulation of less than $60^{\circ}$ (Figures 1 and 2). The examinations were performed with the patient in supine position, at three times: before the operation and then selectively in the third and sixth months after the operation. The contralateral equivalent was the control. The variables studied were the testicular volume, systolic velocity (SV), diastolic velocity (DV), resistance index (RI) and pulsatility index (PI). The statistical method utilized was the model of analysis of variance between repeated measurements.

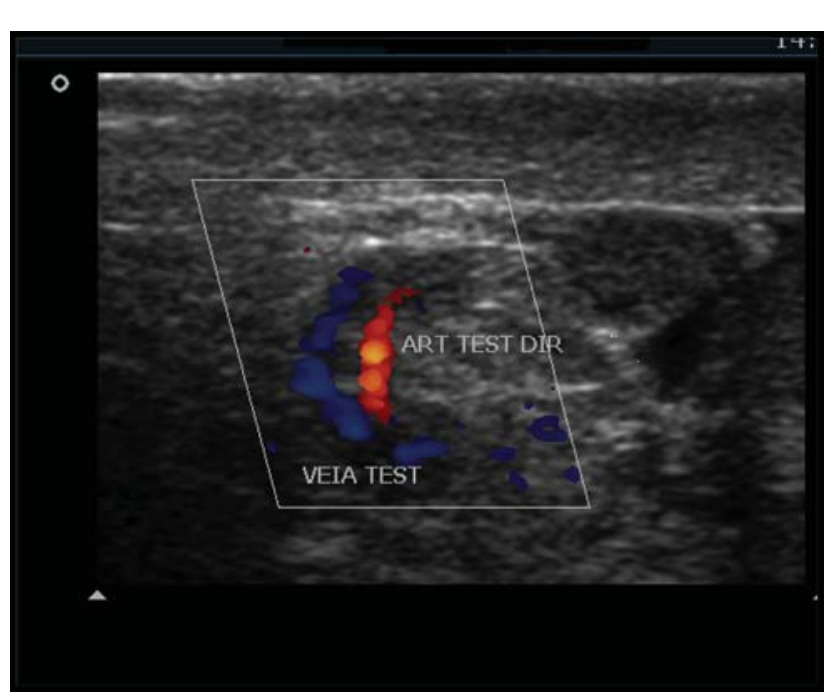

FIGURE 2 - Doppler ultrasonography showing the testicular artery in red and the testicular vein in blue

\section{Results}

No statistically significant alterations in the variables studied were observed over the course of time: testicular volume $(\mathrm{p}=0.197)$; systolic velocity $(\mathrm{p}=$ $0.257)$; diastolic velocity $(\mathrm{p}=0.554)$; resistance index $(\mathrm{p}=0.998) ;$ and pulsatility index $(\mathrm{p}=0.582)$

(Tables 1 to 4 ).

TABLE 1 - Descriptive levels obtained by applying the model of analysis of variance between repeated measurements, to the data

\begin{tabular}{lccc}
\hline Variable & Control vs. operated side & Pre-op vs. 3 months vs. 6 months & Interaction \\
\hline Systolic velocity & 0,992 & 0,257 & 0,502 \\
Diastolic velocity & 0,204 & 0,554 & 0,474 \\
Resistance index & 0,108 & 0,998 & 0,816 \\
Pulsatility index & 0,080 & 0,582 & 0,884 \\
Testicular volume & 0,071 & 0,197 & 0,726 \\
\hline
\end{tabular}


TABLE 2 - Means observed for the variables before the operation

\begin{tabular}{llllll}
\hline$*$ & TV & SV & DV & RI & PI \\
\hline Operated side & 12,12 & 18,40 & 3,13 & 0,81 & 2,36 \\
Control side & 11,36 & 17,52 & 3,62 & 0,77 & 2,01 \\
\hline
\end{tabular}

TABLE 3 - Means observed for the variables in the third month after the operation

\begin{tabular}{llllll}
\hline$*$ & TV & SV & DV & RI & PI \\
\hline Operated side & 11,96 & 18,58 & 3,28 & 0,82 & 2,48 \\
Control side & 11,47 & 18,80 & 3,82 & 0,77 & 2,04 \\
\hline
\end{tabular}

TABLE 4 - Means observed for the variables in the sixth month after the operation

\begin{tabular}{llllll}
\hline$*$ & TV & SV & DV & RI & PI \\
\hline Operated side & 12,0 & 18,96 & 3,21 & 0,81 & 2,34 \\
Control side & 11,76 & 19,48 & 3,99 & 0,77 & 2,00 \\
*TV = Testicular Volume; SV = Systolic Velocity; DV = Diastolic Velocity; & RI = Resistance Index; PI = Pulsatility Index
\end{tabular}

\section{Discussion}

\section{Analysis of testicular volume}

Testicular volume is an important marker for testicular atrophy following corrective surgical operations on patients with inguinal hernias ${ }^{17}$. Wantz ${ }^{6}$ described testicular atrophy as a consequence of ischemic orchitis that could occur in patients who underwent operations with or without prostheses. In the present study, no statistically significant difference was seen between the three observation times in relation to testicular volume ( $p=0.197)$ (Tables 1 to 4 ). Studies conducted to compare the Lichtenstein and extraperitoneal (TEP) techniques have demonstrated a tendency towards decreased testicular volume among patients who underwent the TEP technique, in relation to those who underwent the Lichtenstein technique ${ }^{17}$. The TEP technique puts the elements of the spermatic funiculus in contact with the prosthesis. Another cause of reduced volume and testicular atrophy that has been described is the iatrogenic effect ${ }^{20}$. Dissection must obey good technical principles. An experimental study carried out on rats demonstrated that a simple manipulation of the spermatic funiculus during the operation caused histological and volumetric alterations in the testicles ${ }^{21}$. Surgeons who operate on inguinal hernias using local anesthesia know how important delicate handing of the tissues is for patient comfort $^{22}$. This contributes towards decreasing the iatrogenic effect and preserving the blood flow and testicular volume.

\section{Analysis of the testicular flow}

The arterial flow of the testicles is fundamental for maintaining testicular volume and function ${ }^{23}$. The testicular artery is the principal source of nutrition for testicles, and its diameter may reach $1.5 \mathrm{~mm}^{13}$. The right branch of the aorta emerges at the level L2, from where it continues through the retroperitoneum to penetrate into the spermatic funiculus. There are good anastomoses between the testicular artery and the deferens artery ${ }^{13,23}$. There were no alterations to systolic and diastolic velocity over the course of time, by comparing the results from the three observation times for each group (Tables 1 to 4). Zwiebel and Pellerito ${ }^{24}$ took the expected values for the systolic velocity in the testicular artery to be $4 \mathrm{~cm} / \mathrm{s}$ to $19 \mathrm{~cm} / \mathrm{s}^{24}$. The diastolic velocity was cited as an important parameter for diagnosing severe arterial occlusions. In stenoses in which the vessel diameter is reduced by more than $70 \%$, this velocity increases, but with total occlusion the velocity drops to zero $^{24}$. In the present study, no alteration in this variable was observed. The mean values for the resistance and pulsatility indexes did not present statistically significant differences (Tables 1 to 4). The expected values in the distal testicular artery were described for the resistance index (0.63 to 1.0 ) and for the pulsatility index (1.3 to 5.9$)^{25}$. Diniz et al. ${ }^{27}$ reported that the pulsatility index is an important parameter for evaluating arterial stenoses. This index is more representative for small-caliber vessels, since its calculation encompasses other values from the Doppler wave. In the present study, the resistance index (RI) presented higher mean values $(0.81)$ on the side with the hernia than on the control side (0.77), but this difference was not statistically significant $(\mathrm{p}=0.582)$, nor did the values change in the tests performed in the third and sixth months. For this reason, this difference in the arterial blood flow cannot be attributed to the hernias. Over the observation period, the patients underwent their operations and prostheses were implanted, and the two factors together did not cause alterations in the testicular blood flow, as seen in the tests performed in the third and sixth months. Some authors have attributed a capacity to hernias for altering testicular blood flow ${ }^{11}$. This was not what was seen in the present study. Aydede et al. ${ }^{16}$ observed a decreased 
mean value for the pulsatility index and increased resistance index in a test done on the third postoperative day. This difference had disappeared by the time of the subsequent examination (sixth month), and this was attributed to the trauma of the operation and to tissue edema ${ }^{16}$. These authors did not consider the possibility that these alterations might have occurred because of the inflammatory reaction triggered by the prosthesis. It would have been very useful to observe for how long these flow alterations remained, considering that the subsequent examination was only done in the sixth month after the operation. Ersin et al. ${ }^{28}$ performed early examinations and observed alterations in the systolic and diastolic velocities only in the group that underwent the operation using the laparoscopic extraperitoneal (TEP) technique. The various studies discussed here lead to a common point: preservation of testicular function and fertility in men with inguinal hernias. The techniques, tactics, prostheses and everything that could be related to the surgical correction of hernias need to be considered. Shin et al. ${ }^{19}$ reported on 14 cases of azoospermia among patients who underwent operations using the Lichtenstein technique and concluded that their infertility was related to the use of polypropylene prostheses that had favored obstruction of the vas deferens. Reports like this one from Shin et al. ${ }^{19}$ are rare in the literature and generally are series with few cases. Damage to the vas deferens and testicle are complications from surgical correction for inguinal hernias ${ }^{6,20}$. The incidence of infertility among patients operated because of inguinal hernias is greater than in the general population ${ }^{12}$. However, it needs to be asked whether the normal fibroblastic response developed by the prostheses would be only agent responsible for the ductal obstructions. The iatrogenic effect or even excessive tissue response by some patients cannot be neglected. If the prostheses really are related to these cases of infertility, the physiopathology has not yet been fully clarified. The protection given to the elements of the spermatic funiculus by the cremaster muscle has been cited as one advantage of the Lichtenstein procedure in relation to other techniques in which the prosthesis remains in contact with vessels and nerves ${ }^{26}$. This protection may be increased by using flaps of aponeurosis that are placed between the prosthesis and the funiculus. As demonstrated in the studies by Aydede et al. ${ }^{16}$ and Akbulut et al. ${ }^{17}$, the prosthesis produces different repercussions according to where it has been implanted. Placement of the prosthesis in the pre-peritoneal position, as part of a variety of techniques, has been found to cause more repercussions on the testicle and the testicular flow than does the Lichtenstein technique ${ }^{16,17}$. The latter procedure was the only one that presented homogeneous results in dozens of multicenter studies with recurrence rates of $1 \%$. It is safe, simple, efficient and easy to learn, and it presents high satisfaction rates. A prosthesis positioned anteriorly above the fascia transversalis provides a cure for a hernia, because it covers the whole region of the inguinal floor, is a tension-free repair and also protects the whole region where the tissue presents metabolic defects, with regard to future occurrences ${ }^{5}$. The advances that polypropylene prostheses have brought to hernia treatment are undeniable. There is no reason for retreat: the benefits are indisputable. The present study has contributed towards the conclusion that the prostheses are safe, since it has demonstrated that the arterial flow and testicular volume do not undergo modification following the implantation. This finding is important with regard to maintaining fertility, as observed by Fong and Wantz ${ }^{29}$. However, it cannot be forgotten that prostheses do not consist of inert material. When applied to living tissue, a strong tissue reaction is caused. Experimental studies should be developed whenever new techniques or modification of the present techniques are contemplated. Prostheses are expected to evolve further: discovering their ideal weight and density is a challenge for researchers. New treatment choices may emerge. Use of stem cells, cultivation of tissues in the laboratory, correction of errors in collagen synthesis and cell mediators, and supplying of enzymatic and biochemical deficiencies are directions to be taken up are the directions to be taken by those who are studying the surgical correction of hernias ${ }^{27}$. Bendavid ${ }^{26}$ stated that in the future it is possible that hernias will be classified as diseases connected with metabolism errors and malnutrition ${ }^{27}$. Until then, it is prudent to state that the implantation of prostheses in young patients undergoing infertility treatment should be considered. Fitzgibbons ${ }^{20}$ emphasized that inguinal hernias are a highly prevalent disease among men and that the advantages from using prostheses are still greater than the risks of recurrence.

\section{Conclusion}

No alteration in testicular volume and arterial flow over a six-month period was observed among patients who underwent surgical correction for inguinal hernia using a polypropylene prosthesis.

\section{References}

1. Coob WS, Kercher KW, Heniford T. The argument for lightweight polypropilene mesh in hernia repair. Surg Inn. 2005;12(1):20-7.

2. Klosterhalfen B, Junge K, Klinge U. The lightweight and large porus mesh concept for hernia repair. Exp Rev Med Dev. 2005;2(1):1-15.

3. Shulman AG, Amid PK, Lichtenstein IL. A survey of non-expert surgeons using the open tension-free mesh patch repair for primary inguinal hernias. Int Surg. 1995;80:35-6.

4. Zieren J, Beyersdorff D, Beier KM, Müller JM. Sexual function and testicular perfusion after inguinal hernia repair with mesh. Am J Surg. 2001;181:204-6.

5. Amid PK. Lichtenstein tension-free hernioplasty: its inception, evolution and principles. Hernia. 2004;8(1):1-7. 
6. Wantz GE. Testicular atrophy as a risk of inguinal hernioplasty. Surg Gynecol Obstet. 1982;154:570-1.

7. Amid PK, Lichtenstein IL. Long-term result and current status of the Lichtenstein open tension-free hernioplasty. Hernia. 1998;89(2):89-94.

8. Amid PK, Friis E, Horeyseck, Kux M. A multi-center experience with 6,764 Lichtenstein tension-free herniplasties. Hernia. 1999; 3:47-8.

9. Speranzini MB, Deutsch CR. Avaliação dos resultados da correção das hérnias inguinais e crurais pelos métodos atuais. In: Speranzini MB. Tratamento cirúrgico das hérnias das regiões inguinal e crural: estado Atual. São Paulo: Livraria Atheneu; 2001. p.189-208.

10. Nyhus LM. Individualization of hernia repair: a new era. Surgery. 1993;114:1-2.

11. Beddy P, Ridgway PF, Georghegan T, Peirce C. Inguinal hernia repair protects testicular function: a prospective study of open and laparoscopic herniorraphy. J Am Coll Surg. 2006;203(1):17-23.

12. Yavetz H, Harash B, Yogev L, Homonnai ZT, Paz G. Fertility of men following inguinal hernia repair. Andrologia. 1991;23(6):443-6.

13.Uzzo RG, Lemack GE, Morrissey KP, Goldstein M. Effects of mesh bioprosthesis on the spermatic cord strutures: a preliminary report in a canine model. J Urol. 1999;161:1344-49.

14. Klinge U, Klosterhalfen B, Müller M, Schumpelick V. Foreign body reation to meshes used for the repair of abdominal wall hernias. Eur J Surg. 1999;165:665-73.

15. Goldenberg A, Matone J, Marcondes W, Focchi G. Efeitos da tela de polipropileno no testículo,epidídimo e ducto deferente de cães. Acta Cir Bras. 2001;16(4):226-30.

16. Aydede H, Erhan Y, Sakarya A, Kara E, Ilkgül Ö, Can M. Effect of mesh its localisation on testicular flow and spermatogenesis in patients with groin hernia. Acta Chir Belg. 2003;103:607-10.

17. Akbulut G, Serteser M, Yucel A, Degirmenci B, Yilmaz S, Polat C, San O, Dilek ON. Can laparoscopic hernia repair alter function and volume of testis? Randomized clinical trial. Surg Laparosc Endosc Percutaneous Tech. 2003;13(6):377-81.
18. Goldenberg A, De Paula JF. Effects of polypropylene mesh implanted through inguinotomy in the spermatic funiculus, epididium and testis of dogs. Acta Cir Bras. 2005;20(6):461-7.

19. Shin D, Lipshultz LI, Goldstein M, Barme GA, Fuchs EF, Nagler HM, McCallum SW, Niederberger CS, Schoor RA, Brugh VM, Honig SC. Herniorrhaphy with polypropilene mesh causing inguinal vasal obstruction: a preventable cause of obstrutive azzoospermia. Ann Surg. 2005;241(4):553-8.

20. Fitzgibbons RJ. Can we be sure polypropylene mesh causes infertility? Ann Surg. 2005;241(4):559-61.

21.Lee SL, Jeffrey J, DuBois, Rishi M. Testicular Damage after surgical groin exploration for elective herniorrhaphy. J Pediatr Surg. 2000;35(2):327-30.

22.Lima Neto EV, Goldenberg A, Jucá MJ. Resultados Imediatos da herniorrafia inguinal com anestesia local associada com sedação. Acta Cir Bras. 2003;18(5):478-84.

23.Skandalakis JE, Skandalakis LJ, Colborn GL. Testicular atrophy and neuropathy in herniorrhaphy. Am Surg. 1996;62:775-82.

24.Zwiebel WJ, Pellerito JS. Conceitos básicos da análise do espectro de freqüência Doppler e exame ultra-sônico do fluxo sanguíneo. In: Zwiebel WJ, Pellerito JS. Introdução a ultra-sonografia vascular. 5ed. São Paulo: Elsivier; 2005. p.45-64.

25. Valenti G, Baldassarre E, Torino G. Vas deferens obstruction due to fibrosis after plug hernioplasty. Am Surg. 2006;72(2):137-38.

26. Bendavid R. The unified theory of hernia formation. Hernia. 2004;3(8):171-6.

27. Diniz ALD, Moron AF, Santos MC, Sass N, Pires CR. Dopplervelocimetria das artérias oftálmica e central da retina em gestantes normais. Rev Bras Ginecol Obstet. 2005;27(4):168-73.

28. Ersin S, Aydin U, Makay O, Icoz G, Tamsel S, Sozbilen M. Is the testicular perfusion influenced during laparoscopic inguinal hernia surgery? Surg Endosc. 2006;20(4):685-9.

29.Fong MD, Wantz GE. Prevention of ischaemic orchitis during inguinal hernioplasty. Surg Gynecol Obstet. 1992;174:399-402.

\section{Correspondence:}

Edgar Valente de Lima Neto

Rua Guarabu, 147

57052-505 Maceió - AL Brazil

evlimant@uol.com.br
Conflict of interest: none Financial source: none

Received: March 16, 2007 Review: May 14, 2007

Accepted: June 15, 2007

\section{How to cite this article}

Lima Neto EV, Goldenberg A, Jucá MJ. Prospective study on the effects of a polypropylene prosthesis on testicular volume and arterial flow in patients undergoing surgical correction for inguinal hernia. Acta Cir Bras. [serial on the Internet] 2007 July-Aug 22(4). Available from URL: http://www.scielo.br/acb 